\title{
Analysis of the Profitability and Competitiveness of Rabbit Value Chains in Benin
}

\author{
Jean Adanguidi ${ }^{1}$ \\ ${ }^{1}$ Faculty of Economic and Management, University of Abomey-Calavi, Benin \\ Correspondence: Jean Adanguidi, Faculty of Economic and Management, University of Abomey-Calavi, 03 BP \\ 0984, Benin. Tel: 229-9694-5618. E-mail: a60j60@gmail.com
}

Received: November 23, 2019

Accepted: December 24, 2019

Online Published: January 15, 2020

doi:10.5539/jas.v12n2p151

URL: https://doi.org/10.5539/jas.v12n2p151

\begin{abstract}
Rabbit farming in Benin can offer enormous potential for job and income creation for both rural and urban populations and can provide an alternative to crop production that is now more threatened by the adverse effects of climate change. Unfortunately, useful information on the rabbit meat market as well as on the different value chains and their performance is not available. The objective of this study is to analyze the profitability of the rabbit value chains and their competitiveness in Benin. To achieve this, we surveyed 133 people, including 64 rabbit farmers, 11 merchants, 23 restaurant owners and processors and 35 rabbit consumers. We then analyzed the financial profitability of rabbit production and the competitiveness of different rabbit values. Our results showed that rabbit meat production is not competitive in the southern regions of the country and that marketing and processing make rabbit value chains more competitive.
\end{abstract}

Keywords: value chains, rabbit, Profitability, competitiveness, policy analysis matrix, Benin

\section{Introduction}

For several decades, agricultural development policies and strategies implemented in Benin have given pride of place to crop production at the expense of livestock production, despite the important role that it plays in family farming, trade, population feeding and even in rural people's adaptation strategies to the adverse effects of climate change. However, everyone knows that, if properly monitored and organized, livestock farming can make a valuable contribution to the creation of decent jobs and the improvement of the incomes of vulnerable groups, as well as to the improvement of food and nutritional security for populations (Montero-Vicente, 2018).

At a time when youth unemployment is growing at an alarming rate in our countries, it is important to explore the many opportunities that livestock farming can offer as a source of job creation. In this respect, rabbit farming can provide a substantial income for young people seeking employment and contribute to improving the diet of urban and rural households (Lebas et al., 1996; Gnimadi, 1998). It can offer significant development potential and represent a source of self-employment for young people and women (Oseni \& Lukefahr, 2014; Monsia \& Agbèdè, 2014).

In Benin, the rabbit sector is not sufficiently organized and political decision-makers at all levels lack information on its real potential. Useful information on the rabbit meat market as well as on the different value chains and their performance is not widely available.

It is to fill this gap that this study was carried out in order to analyse the profitability of the rabbit value chains and their competitiveness in Benin.

\section{Methods}

\subsection{Sampling Method}

In Benin, rabbit farming is mainly developed in the southern part of the country. We then concentrated most of our study on this densely populated part of Benin (10\% of the territory, which covers more than $60 \%$ of the population, i.e., a density of more than 500 inhabitants per $\mathrm{km}^{2}$ ). The sampling method used depends on the type of actors considered:

$\checkmark \quad$ For rabbit breeders (rabbit producers or breeders), a sampling frame was first established from the list of breeders by region obtained from various professional agricultural organization, NGOs and the technical 
structures of the Ministry in charge of Agriculture. Then, a random sampling of rabbit breeders was done by region using the pseudo-random numbers available in Excel 2007 software.

$\checkmark \quad$ The choice of other actors in the rabbit value chains was made from rabbit breeders to traders, processors, restaurants owners, consumers of rabbit meat, food suppliers and other inputs for rabbits.

$\checkmark \quad$ The choice of consumers surveyed was made using the so-called accidental sampling technique, which consists in positioning an interviewer with a trader, restaurant owner or processor at a randomly selected time between 9 a.m. and 6 p.m. Once on site, the investigator will investigate five rabbit consumers who arrived on the scene after him.

A total of 133 people were surveyed during the quantitative phase, namely (Table 1): 64 rabbit breeders, 11 traders, 23 restaurant owners and processors and 35 rabbit consumers. To this number, it will be necessary to add five rabbit breeders' organizations, two NGOs that support rabbit breeders and a few resource persons (Technician from the Ministry of Agriculture, researchers, distributors of rabbit food or veterinary products).

Table 1. Distribution of the sample according to regions and categories of actors

\begin{tabular}{|c|c|c|c|c|c|c|c|}
\hline \multirow[b]{2}{*}{ Actor } & \multicolumn{6}{|c|}{ Region } & \multirow[b]{2}{*}{ Ensemble } \\
\hline & $\begin{array}{l}\text { Atlantique/ } \\
\text { Littoral }\end{array}$ & $\begin{array}{l}\text { Borgou/ } \\
\text { Alibori }\end{array}$ & $\begin{array}{l}\text { Mono/ } \\
\text { Couffo }\end{array}$ & $\begin{array}{l}\text { Ouémé/ } \\
\text { Plateau }\end{array}$ & $\begin{array}{l}\text { Zou/ } \\
\text { Collines }\end{array}$ & $\begin{array}{l}\text { Atacora/ } \\
\text { Donga }\end{array}$ & \\
\hline Producer & 20 & 10 & 10 & 10 & 12 & 2 & 64 \\
\hline Trader & 5 & 0 & 0 & 4 & 1 & 1 & 11 \\
\hline Restaurant or Butcher specialized in rabbit meat & 5 & 3 & 4 & 6 & 4 & 1 & 23 \\
\hline Consumer & 10 & 5 & 5 & 10 & 2 & 0 & 35 \\
\hline Total & 40 & 18 & 19 & 30 & 22 & 4 & 133 \\
\hline
\end{tabular}

\subsection{Data Used}

Several types of information were collected from respondents. This includes data on operating accounts, strengths, weaknesses, threats and opportunities.

\subsection{Data Analysis}

\subsubsection{Financial Profitability}

Several profitability indicators have been calculated. It is about:

$\checkmark \quad$ Gross product $(G P)$ : By designating rabbit production sold by PS (in $\mathrm{Kg}$ ), self-consumed production by $\mathrm{SCP}$ (in $\mathrm{Kg}$ ), production not yet sold by PNS (in $\mathrm{Kg}$ ) and selling price per Kilogram by SP (in FCFA $\times \mathrm{Kg}^{-1}$ ), the gross product is calculated by the formula:

$$
\mathrm{GP}=(\mathrm{PS}+\mathrm{SCP}+\mathrm{PNS}) \times \mathrm{SP}
$$

$\checkmark$ Added Value $(A V)$ : it is equal to the difference between the gross product (GP) and the value of intermediate consumption (IC):

$$
\mathrm{VA}=\mathrm{GP}-\mathrm{IC}
$$

Intermediate consumption (IC) being goods and services fully consumed during a production cycle. This includes food, veterinary products, water, equipment maintenance and repair costs, etc.

$\checkmark \quad$ Gross operating income (GOI): It is equal to,

$$
\mathrm{GOI}=\mathrm{VA}-(\text { Labour compensation }+ \text { Financial Expenses }+ \text { Taxes })
$$

According to Fabre (1994), GOI represents the agent's economic gain (or loss) after all current operating expenses have been paid. It therefore refers to the operating profit once all operating costs for the financial year have been deducted from the value of production: intermediate consumption, labour, financial expenses and taxes.

$\checkmark \quad$ Net operating income (NOI) or profit: It is calculated according to the following formula:

$$
\mathrm{NOI}=\mathrm{VA}-(\mathrm{RL}+\mathrm{T}+\mathrm{Am})=\mathrm{RBE}-\mathrm{VD}
$$

Where, RL is the remuneration of labour, $\mathrm{T}$ represents taxes and VD is the value of depreciation. The NOI expresses the economic gain or loss taking into account previous investments, i.e., the resources that the agent had to capitalize previously (Fabre, 1994). 
$\checkmark \quad$ Total production costs (TPC): These are intermediate consumption, depreciation of livestock equipment/materials, and labour costs (family and employed). After the calculation of the production costs, the structure of these costs was established. This is, in fact, the share of each expenditure item in the total production costs of the rabbit. And,

$\checkmark \quad$ Profitability ratios: Two ratios are calculated: the ratio between added Value and intermediate consumption and the ratio between the NOI and total production costs.

\subsubsection{Competitiveness Analysis}

The Policy Analysis Matrix (PAM) was used to analyse the competitiveness of rabbit value chains in Benin. We have calculated the main indicators of the comparative advantage of the different value chains (Table 2).

Table 2. Policy Analysis Matrix

\begin{tabular}{lllll}
\hline & Recipe & Exchangeable inputs & Domestic resources & Profit \\
\hline Market price & $\mathrm{A}$ & $\mathrm{B}$ & $\mathrm{C}$ & $\mathrm{D}$ \\
Reference price & $\mathrm{E}$ & $\mathrm{F}$ & $\mathrm{G}$ & $\mathrm{H}$ \\
Transfers & $\mathrm{I}$ & $\mathrm{J}$ & $\mathrm{K}$ & $\mathrm{L}$ \\
\hline
\end{tabular}

Note. $\mathrm{A}=$ market price of the products; $\mathrm{B}=$ market price of tradable inputs; $\mathrm{C}=$ market price of non-tradable inputs; $\mathrm{E}=$ reference price of the products; $\mathrm{F}=$ reference price of tradable inputs; $\mathrm{G}=$ reference price of non-tradable inputs; Profits (D, H or L) $=$ [Revenues] - [Costs of tradable and non-tradable inputs]; Divergence $(\mathrm{I}, \mathrm{J}, \mathrm{K}$ or $\mathrm{L})=[$ Market price $]-[$ Reference price $]$.

The first line of this matrix makes it possible to measure the profitability of the sector. It refers to the revenues and prices observed on the market. These are the market prices actually received by farmers, collectors, processors and traders.

The second line shows the economic efficiency of the operators in the sector. To establish this line, it is necessary to estimate the reference prices. For tradable goods, the reference prices are the international parity prices (import parity price for importable goods and export parity price for exportable goods).

The third line shows the differences between private and social profitability. It corresponds to the negative effects of the policy and shows the imperfections of the market.

The Domestic Resource Cost (DRC) Ratio was the main competitiveness indicator used. It measures the efficiency of the system at the reference price. It is calculated by the formula:

$$
\mathrm{DRC}=\frac{\mathrm{G}}{\mathrm{E}-\mathrm{F}}
$$

When the DRC $<1$, the added Value chain (AVC) studied has a comparative advantage in that it uses fewer factors of production than it generates added value. On the other hand, when the DRC $>1$, then the AVC studied uses more domestic resources (labour, capital) than it generates added value. If the $\mathrm{DRC}=1$, the economic balance does not allow for a gain or protect foreign trade through domestic production.

We also calculated the following indicators:

$\checkmark \quad$ The factor cost ratio or Cost-Benefit ratio (CBR), which measures the motivation of rabbit breeders to produce rabbit. This ratio indicates a private profit when it is less than 1 (Fabre, 1994);

$\checkmark \quad$ The nominal protection coefficient for products $(N P C p=A / E)$ and for tradable inputs $\left(N P C_{T I}=B / F\right)$. An NPC greater than 1 shows that the tradable product or inputs are subsidized. However, when the NPC is less than 1 , the product or tradable inputs are taxed;

$\checkmark \quad$ The effective protection coefficient $[\mathrm{EPC}=(\mathrm{A}-\mathrm{B}) /(\mathrm{E}-\mathrm{F})]$, which is an aggregate measure of the protection rate of the productive system taking into account simultaneously the effects of distortions on the product market and on the market for tradable inputs (Fabre, 1994);

$\checkmark \quad$ The profit ratio or profitability ratio (PR), which measures the proportion in which private profit exceeds community profit due to transfers caused by market distortions and economic policies;

The subsidy rate (SR), which is equal to the sum of the transfers in relation to the value of the protection at the reference price. It helps to measure the importance of the degree of subsidy or taxation enjoyed by the production system in question; 
$\checkmark \quad$ The equivalent of the production subsidy (EPS), which refers to the net transfer (\% of social income) induced by the combined effect of distortions, market imperfections and the existence of externality to the benefit of the rabbit breeder. It is the equivalent tariff (of a tax or subsidy) that must be applied to allow the rabbit breeder to maintain his profit at the same level if distortions, market imperfections and externalities are eliminated.

It should be noted that in the AVCs analyzed, work equipment (cages, feeders, waterers, cutters, etc.) is generally acquired with own funds. For this equipment, the annuity is obtained by the capital recovery coefficient method. This coefficient gives the annual payment amount (APA) with compound interest on the outstanding balance. If $\varphi$ is used to designate the interest rate, $n$ the lifetime of the equipment and VE the value of the equipment, we have then:

$$
\mathrm{APA}=(\mathrm{VE}) \times(\text { Capital recovery coefficient })
$$

where, the "Capital recovery coefficient" is equal to $\frac{\varphi(\varphi+1)^{\mathrm{n}}}{(\varphi+1)^{\mathrm{n}}-1}$.

Small agricultural equipment includes, among other things, cutting tools, hoe, axe, knife, etc. These tools were considered to be produced mainly locally from recovered or imported metals. We adopted the fixed cost decomposition coefficients proposed by Lançon (2000): 0.50 for intermediate consumption, 0.40 for unskilled labour and 0.10 for capital cost.

\section{Results and Discussion}

\subsection{Profitability of Rabbit Farming}

\subsubsection{Analysis of Production Costs}

The cost analysis (Table 3) shows that the production of one kilogram of rabbit carcass costs on average CFAF 1908. A comparison of the total costs of rabbit carcass production by region shows that:

$\checkmark \quad$ The departments of Alibori and Borgou have the highest costs: $2084 \mathrm{FCFA} \times \mathrm{Kg}^{-1}$.

$\checkmark \quad$ The departments of Ouémé and Plateau are in second place: 1994 FCFA $\times \mathrm{Kg}^{-1}$ of carcass.

$\checkmark \quad$ The departments of Atacora and Donga have the lowest costs: 1716 FCFA $\times \mathrm{Kg}^{-1}$ of carcass.

The cost of intermediate consumption varies between CFAF $858 \times \mathrm{Kg}^{-1}$ of carcass in the departments of Atacora and Donga and CFAF $1424 \times \mathrm{Kg}^{-1}$ in the departments of Alibori and Borgou. This cost represents on average $60 \%$ of the total production costs of rabbits.

Food costs alone account for an average of $64 \%$ of the cost of intermediate consumption, with the departments of Ouémé and Plateau recording the highest rate (71\%). The comparison of the different cost items also shows that power supply represents the highest item (38\% of total production costs). The departments of Borgou and Alibori have the highest rate (with 42\%) followed by the departments of Atlantique and Littoral (40\%). This will therefore mean that in order to reduce rabbit production costs and thereby improve its profitability, it will be essential to work on reducing feeding costs.

The second expense item in production costs varies by region. In the Atlantique and Littoral departments, labour costs represent the second most important item (27.5\% of total costs), while in the other regions, depreciation is the second most important item (16 to $32 \%$ of total costs). This will mean that to improve the profitability of rabbits, labour productivity will have to be increased in the Atlantique and Littoral departments, while in the other regions, production will have to be further increased.

\subsubsection{Added Value and Operating Results}

For each region, we have calculated certain profitability indicators for rabbit farming (Table 4). According to the results of our analysis, we can make the following comments:

$\checkmark \quad$ All departments in Benin have a positive added value, which means that rabbit farming generates financial gains once all current operating expenses have been paid. Two regions have the highest values, namely the Atlantique and Littoral departments (1472 FCFA $\times \mathrm{Kg}^{-1}$ of rabbit carcass produced) and the Ouémé and Plateau departments (1668 FCFA $\times \mathrm{Kg}^{-1}$ of rabbit carcass produced). The departments of Borgou, Alibori, Atacora and Donga are in last place.

$\checkmark \quad$ The trend observed in terms of added Value was also observed in terms of operating results (Gross operating income and Net operating income): rabbit breeders in the departments of Ouémé and Plateau as well as those in the Atlantique and Littoral departments have the highest profits $\left(774 \mathrm{FCFA} \times \mathrm{Kg}^{-1}\right.$ and $686 \mathrm{FCFA} \times$ $\mathrm{Kg}^{-1}$ of carcass produced respectively). 
$\checkmark \quad$ The ratio of added Value to intermediate consumption shows that 100 CFA francs invested in rabbit breeding generates 117 CFA francs. The highest ratio was observed in the departments of Ouémé and Plateau where an expenditure of 100 CFA francs yields 165 CFA francs. The lowest value was observed in Borgou and Alibori departments where 100 FCFA brought in only 76 FCFA. It is therefore understandable why the number of rabbit breeders is likely to increase in the departments of Ouémé and Plateau, while in the departments of Borgou and Alibori, there is a risk that the number will decrease.

$\checkmark \quad$ The NOI/TPC ratio for the entire sample is 0.29 , which means that an expenditure of 100 CFA francs on rabbit breeding earns $29 \mathrm{CFA}$ francs as a net profit. However, there is a high value for the Atlantique and Littoral departments $(0.41)$ followed by the Ouémé and Plateau departments $(0.34)$.

Table 3. Cost and structure of rabbit production costs $\left(\mathrm{FCFA} \times \mathrm{Kg}^{-1}\right.$ of carcass)

\begin{tabular}{|c|c|c|c|c|c|c|c|}
\hline \multirow[b]{2}{*}{ Heading } & \multicolumn{6}{|c|}{ Region } & \multirow[b]{2}{*}{ Ensemble } \\
\hline & $\begin{array}{l}\text { Atlantique/ } \\
\text { Littoral }\end{array}$ & $\begin{array}{l}\text { Borgou/ } \\
\text { Alibori }\end{array}$ & $\begin{array}{l}\text { Mono/ } \\
\text { Couffo }\end{array}$ & $\begin{array}{l}\text { Ouémé/ } \\
\text { Plateau }\end{array}$ & $\begin{array}{l}\text { Zou/ } \\
\text { Collines }\end{array}$ & $\begin{array}{l}\text { Atacora/ } \\
\text { Donga }\end{array}$ & \\
\hline Feeding & 39.7 & 42.1 & 37.3 & 36.3 & 36.3 & 32.2 & 38.3 \\
\hline Maintenance of the premises & 16.9 & 10.4 & 7.0 & 7.2 & 6.3 & 4.3 & 10.4 \\
\hline Veterinary care (products, intervention, etc.) & 6.1 & 15.9 & 12.6 & 7.3 & 14.0 & 13.6 & 10.6 \\
\hline Other expenses & 0.1 & 0.0 & 1.0 & 0.0 & 0.0 & 0.0 & 0.2 \\
\hline Intermediate consumption & 62.8 & 68.4 & 57.8 & 50.7 & 56.6 & 50.0 & 59.5 \\
\hline Intermediate consumption (FCFA/Kilogram of Carcass) & 1177.9 & 1424.3 & 1054.0 & 1012.1 & 1044.3 & 858.4 & 1136.1 \\
\hline Family labour force & 6.9 & 5.8 & 6.8 & 12.2 & 10.9 & 9.3 & 8.4 \\
\hline Salaried workforce & 20.6 & 9.4 & 9.8 & 9.8 & 4.3 & 8.9 & 12.0 \\
\hline Depreciation of equipment and infrastructure & 9.7 & 16.4 & 25.6 & 27.3 & 28.3 & 31.8 & 20.1 \\
\hline Total production cost $\left(F C F A \times \mathrm{Kg}^{-1}\right)$ & 1875.6 & 2083.5 & 1823.1 & 1994.4 & 1845.8 & 1715.7 & 1907.8 \\
\hline
\end{tabular}

Table 4. Added Value, operating results $\left(\mathrm{FCFA} \times \mathrm{Kg}^{-1}\right.$ rabbit carcass) and profitability ratio

\begin{tabular}{|c|c|c|c|c|c|c|c|}
\hline \multirow[b]{2}{*}{ Heading } & \multicolumn{6}{|c|}{ Region } & \multirow[b]{2}{*}{ Ensemble } \\
\hline & $\begin{array}{l}\text { Atlantique/ } \\
\text { Littoral }\end{array}$ & $\begin{array}{l}\text { Borgou/ } \\
\text { Alibori }\end{array}$ & $\begin{array}{l}\text { Mono/ } \\
\text { Couffo }\end{array}$ & $\begin{array}{l}\text { Ouémé/ } \\
\text { Plateau }\end{array}$ & $\begin{array}{l}\text { Zou/ } \\
\text { Collines }\end{array}$ & $\begin{array}{l}\text { Atacora/ } \\
\text { Donga }\end{array}$ & \\
\hline Gross product (GP): & 2650.0 & 2500.0 & 2261.6 & 2680.3 & 2210.3 & 2000.0 & 2467.9 \\
\hline Intermediate consumptions (IC) & 1177.9 & 1424.3 & 1054.0 & 1012.1 & 1044.3 & 858.4 & 1136.1 \\
\hline Added Value $(A V)$ : & 1472.1 & 1075.7 & 1207.6 & 1668.2 & 1166.0 & 1141.6 & 1331.7 \\
\hline Family labour force & 130.0 & 121.6 & 123.4 & 242.4 & 200.4 & 160.0 & 159.3 \\
\hline Salaried workforce & 386.4 & 195.2 & 178.2 & 194.6 & 78.7 & 152.0 & 229.0 \\
\hline Gross operating income (GOI): & 955.7 & 758.9 & 905.9 & 1231.1 & 886.9 & 829.6 & 943.4 \\
\hline Depreciation & 181.3 & 342.4 & 467.5 & 545.2 & 522.4 & 545.3 & 383.4 \\
\hline Total production costs (TPC) & 1875.6 & 2083.5 & 1823.1 & 1994.4 & 1845.8 & 1715.7 & 1907.8 \\
\hline Net operating income (NOI) & 774.4 & 416.5 & 438.5 & 685.9 & 364.5 & 284.3 & 560.0 \\
\hline \multicolumn{8}{|l|}{ Ratio } \\
\hline$V A / I C$ & 1.25 & 0.76 & 1.15 & 1.65 & 1.12 & 1.33 & 1.17 \\
\hline NOI/TPC & 0.41 & 0.20 & 0.24 & 0.34 & 0.20 & 0.17 & 0.29 \\
\hline
\end{tabular}

\subsection{Analysis of the Competitiveness of Rabbit Value Chains}

\subsubsection{Mapping of Rabbit Value Chains}

The rabbit sector in Benin is structured around two value chains (Figure 1):

$\checkmark \quad$ The rabbit meat value chain processed (braised/grilled or skewer form): Different types of actors are involved in this value chain:

- $\quad$ Broker who collects rabbits from rabbit breeders. He is himself a breeder and has relationships with traders.

- $\quad$ Traders, most of whom are also rabbit breeders and who have contacts with restaurants specializing in rabbit meat processing.

- $\quad$ Restaurant owners, who are also breeders in $40 \%$ of cases. 
$\checkmark \quad$ The fresh rabbit meat value chain: It drains rabbit carcasses to fixed sales points (belonging to the Beninese Association of Rabbit breeders or to private individuals) or fish shops in the city of Cotonou. The key players here are traders and rabbit breeders.

According to the literature, the structure of value chains varies from country to country. Baviera-Puig et al. (2017) in their study of the Rabbit meat sector value chain in Spain identified four components in the rabbit meat chain: producers, input suppliers, abattoirs and cutting plants and distribution. Mengesha et al. (2018) in their study of Value chain analysis of fruits in Ethiopia found that mango and avocado producer, input suppliers, collectors, retailers, wholesalers and consumers were the main actors in mango and avocado value chain.

\subsubsection{Analysis of the Financial Profitability of Value Chains}

The two value chains studied have added value and positive benefits (Table 5). The processed rabbit meat value chain is apparently the most profitable. Rabbit breeders also invest more in both value chains than other actors. They are also the ones who make the most profit (49\% of the profits generated in the processed rabbit meat value chain and $94 \%$ for the fresh meat value chain).

However, when we take into account the efforts that each group of actors makes in the different value chains, we realize that in the processed rabbit meat value chain, processors earn more than they invest. They contribute $28.5 \%$ to intermediate consumption in the value chain but obtain $41 \%$ of the added value generated. They contribute $33 \%$ to the total costs of the processed rabbit meat value chain but receive $45 \%$ of the profits from the value chain. In short, processors earn more than they invest in this added value chain. In the fresh rabbit meat value chain, rabbit breeders earn more than they invest.

This result is different from those of Mengesha et al. (2018) in Ethiopia, where they found that the wholesalers received the highest marketing margin $(34.62 \%)$ and highest profit share $(36.75 \%)$, while the producers received the least marketing margins (15.17\%) from avocado and mango trade.

\subsubsection{Analysis of the Competitiveness of Value Chains}

The analysis of the results in Table 6 shows that the Domestic Resource Cost (DRC) ratio is higher than 1 in the southern regions of Benin (Atlantique, Littoral, Mono, Couffo, Ouémé, and Plateau departments). This means that to produce 1 CFAF of added value in these departments, rabbit breeders use resources whose value is greater than 1 CFAF. There is therefore a loss of wealth for the community, i.e., rabbit meat production in these regions is not competitive. On the other hand, in the central and northern departments of the country, rabbit production is becoming competitive since the DRC is less than 1.

The results in Table 7 show that the two value chains studied have a comparative advantage in rabbit meat production. This means that to produce $1 \mathrm{CFAF}$ of added value, resources whose value is less than $1 \mathrm{CFAF}$ will be used.

By comparing the results of Table 6 with those of Table 5, it can be deduced that it is marketing and processing that enable the two value chains studied to be competitive. Therefore, to improve the competitiveness of rabbit breeding and boost the sector's contribution to the national economy, it will be necessary to act on processing and marketing.

The effective protection coefficient (EPC) is greater than 1 for all regions (Table 6) and for all value chains (Table 7). As a result, rabbit breeders benefit from an incentive. This means that the combination of transfers on products and on intermediate consumption (tradable goods) results from (Fabre 1994):

$\checkmark \quad$ an effective distribution of income greater than it would be if international prices were applied (all other things being equal);

$\checkmark \quad$ an added value distributed to agents that is higher than what it represents economically for the community.

The nominal product protection coefficient (NPC) is greater than 1 in all regions. This means that the different actors in these value chains enjoy a higher income than they would without the policy (here tax) and market distortions. 


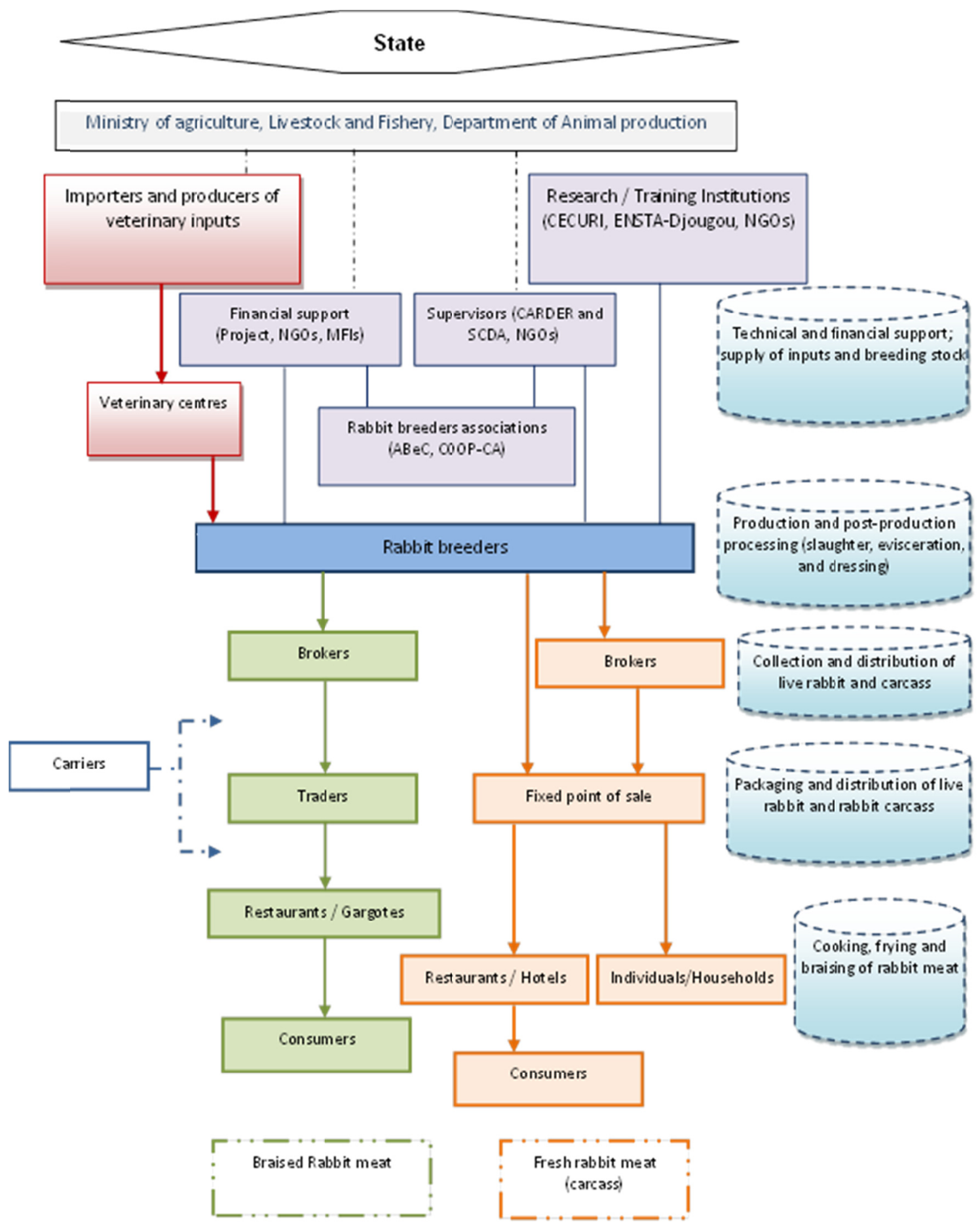

Figure 1. Mapping of rabbit value chains in Benin 
Table 5. Indicators of financial profitability of value chains

\begin{tabular}{|c|c|c|c|c|c|c|c|c|}
\hline \multirow{2}{*}{ Actors } & \multicolumn{2}{|c|}{ Intermediate consumption } & \multicolumn{2}{|l|}{ Added Value } & \multicolumn{2}{|c|}{ Total production cost } & \multicolumn{2}{|c|}{ Net operating income } \\
\hline & $F C F A \times \mathrm{Kg}^{-1}$ & $\%$ & $F C F A \times \mathrm{Kg}^{-1}$ & $\%$ & $F C F A \times \mathrm{Kg}^{-1}$ & $\%$ & $F C F A \times \mathrm{Kg}^{-1}$ & $\%$ \\
\hline \multicolumn{9}{|c|}{ Processed rabbit meat value chain } \\
\hline Production & 1136.1 & 59.7 & 1331.7 & 48.8 & 1907.8 & 54.7 & 560.0 & 48.9 \\
\hline Commercialization & 224.9 & 11.8 & 274.9 & 10.1 & 427.0 & 12.2 & 72.8 & 6.4 \\
\hline Rabbit processing & 542.4 & 28.5 & 1122.2 & 41.1 & 1153.3 & 33.1 & 511.3 & 44.7 \\
\hline Total & 1903.4 & 100 & 2728.8 & 100 & 3488.1 & 100 & 1144.1 & 100 \\
\hline \multicolumn{9}{|c|}{ Fresh rabbit meat value chain } \\
\hline Production & 1177.9 & 80.0 & 1472.1 & 84.8 & 1875.6 & 78.8 & 774.4 & 93.6 \\
\hline Commercialization & 293.7 & 20.0 & 263.5 & 15.2 & 504.6 & 21.2 & 52.6 & 6.4 \\
\hline Total & 1471.6 & 100 & 1735.5 & 100 & 2380.2 & 100 & 827.0 & 100 \\
\hline
\end{tabular}

Table 6. Indicators of rabbit comparative advantage by region

\begin{tabular}{llllllll}
\hline \multirow{2}{*}{ Indicators } & \multicolumn{9}{c}{ Region } \\
\cline { 2 - 6 } & $\begin{array}{l}\text { Atacora/ } \\
\text { Donga }\end{array}$ & $\begin{array}{l}\text { Atlantique/ } \\
\text { Littoral }\end{array}$ & $\begin{array}{l}\text { Borgou/ } \\
\text { Alibori }\end{array}$ & $\begin{array}{l}\text { Mono/ } \\
\text { Couffo }\end{array}$ & $\begin{array}{l}\text { Ouémé/ } \\
\text { Plateau }\end{array}$ & $\begin{array}{l}\text { Zou/ } \\
\text { Collines }\end{array}$ & Bénin \\
\hline Cost-Benefit ratio (CBR) & 0.79 & 0.59 & 0.73 & 0.71 & 0.83 & 0.75 & 0.66 \\
Economic profitability (EP) & 37.17 & -696.31 & 20.08 & -73.57 & -237.15 & 247.17 & -166.68 \\
Domestic Resource Cost Ratio (DRCR) & 0.96 & 3.16 & 0.98 & 1.09 & 1.30 & 0.78 & 1.21 \\
Nominal Protection Coefficient (NPC) & 1.21 & 2.37 & 1.24 & 1.37 & 1.38 & 1.11 & 1.49 \\
Effective Protection Coefficient (EPC) & 1.35 & 5.62 & 1.45 & 1.71 & 1.71 & 1.16 & 1.98 \\
Cost-Effectiveness Ratio (CR) & 6.58 & -1.07 & 18.95 & -5.44 & -1.00 & 1.31 & -3.15 \\
Producer Subsidy Rate (PSR) & 0.13 & 1.29 & 0.18 & 0.29 & 0.29 & 0.04 & 0.42 \\
Equivalent of the Producer Subsidy (EPS) & 0.10 & 0.54 & 0.14 & 0.21 & 0.21 & 0.03 & 0.28 \\
\hline
\end{tabular}

Table 7. Indicators of rabbit comparative advantage by value chain

\begin{tabular}{lll}
\hline Indicator & Fresh meat & Processed meat \\
\hline Financial Cost-Benefit Ratio (FCBR) & 0.60 & 0.66 \\
Economic Profitability (EP) & 93.37 & 499.37 \\
Domestic Resource Cost Ratio (DRC) & 0.91 & 0.74 \\
Nominal Protection Coefficient for Products $\left(\mathrm{NPC}_{\mathrm{p}}\right)$ & 1.45 & 1.17 \\
Effective Protection Coefficient (EPC) & 1.73 & 1.22 \\
Cost-Effectiveness Ratio (CR) & 7.38 & 1.59 \\
Producer Subsidy Rate (PSR) & 0.36 & 0.10 \\
Equivalent of the Producer Subsidy (EPS) & 0.25 & 0.09 \\
\hline
\end{tabular}

\section{Conclusions}

The objective of this research was to understand the functioning of the rabbit meat market in Benin using a value chain approach. To achieve this, qualitative and quantitative data were collected from a sample of 133 stakeholders including 64 rabbit breeders, 11 traders, 23 processors and restaurant owners and 35 rabbit consumers. We also interviewed five producer organizations, two non-governmental organizations and about thirty resource persons.

From our investigations, it appears that the breeders sell the rabbit either live or in the form of a carcass. Rabbit meat production is not competitive in the southern regions of the country. Marketing and processing make rabbit value chains more competitive.

Two value chains have been identified, namely the processed rabbit meat value chain and the fresh rabbit meat value chain. In the processed rabbit meat value chain, processors earn more than they invest. In the fresh rabbit meat value chain, it is the rabbit breeders who earn more than they invest. Both value chains are profitable, but the processed rabbit meat value chain seems to be the most profitable. The processed rabbit meat value chain is more competitive. 


\section{References}

Baviera-Puig, A., Buitrago-Vera, J., Escriba-Perez, C., \& Montero-Vicente, L. (2017). Rabbit meat sector value chain. World Rabbit Sci., 25, 95-108. https://doi.org/10.4995/wrs.2017.6565

Djago, A. Y. (1998). Zootechnie et gestion d'une exploitation cunicole (Rapport FAO Cotonou).

Djago, A. Y., Kpodékon, M., \& Lebas, F. (2010). Guide pratique d'élevage de lapin sous les tropiques (2nd ed., p. 119). CECURI (Centre Cunicole de Recherche et d'Information), Abomey-Calavi.

Gnimadi, A. (1998). La filière cunicole au Bénin: Commercialisation, rentabilité et organisation des acteurs (Rapport FAO Tomes 1 et 2). Cotonou, Benin.

Goudjo, E. A. (2010). Évaluation des performances de reproduction des lapines en sélection et des femelles croisées avec des mâles de souche INRA 1777 au CECURI (Centre Cunicole de Recherche et d'Information) Bénin (Mémoire pour Master Professionnel, Université d'Abomey-Calavi, Benin).

Henaff, R., \& Jouve, D. (1988). Mémento de l'éleveur de lapins. AFC Editeur Lempdes.

INSAE. (2016). Statistiques sur les importations et les exportations. Retrieved from http://www.insae-bj.org/ echanges-exterieure.html

Lançon, F. (2000). Etude de la compétitivité de la riziculture guinéenne (Rapport de la $1^{\text {ère }}$, Mission d'appui de l'ADRAO, Mars 4-19, 2000, p. 32).

Lebas, F. (2006). Alimentation et santé digestive chez le lapin. Cuniculture Magazine, 33, 63-70.

Lebas, F., Coudert, P., de Rochambeau, H., \& Thébault, R. G. (1996). Le lapin: Élevage et pathologie. Collection FAO: Production et Santé Animales $N^{\circ} 19$ (p. 227).

Mengesha, S., Abate, D., Adamu, C., Zewde, A., \& Addis, Y. (2018). Value chain analysis of fruits: The case of mango and avocado producing smallholder farmers in Gurage Zone, Ethiopia. Journal of Development and Agricultural Economics, 11(5), 102-109. https://doi.org/10.5897/JDAE2018.1038

Montero-Vicente, L., Escribá-Pérez, C., Baviera-Puig, A., \& Buitrago-Vera, J. (2018). Analysis of the commercial value of rabbit meat based on positioning of the different types of fresh meat. Spanish Journal of Agricultural Research, 16(3), e0110. https://doi.org/10.5424/sjar/2018163-13407

Oseni, S. O., \& Lukefahr, S. D. (2014). Rabbit production in low-input systems in Africa: Situation, knowledge and perspectives—A review. World Rabbit Sci., 22, 147-160. https://doi.org/10.4995/wrs.2014.1348

\section{Copyrights}

Copyright for this article is retained by the author(s), with first publication rights granted to the journal.

This is an open-access article distributed under the terms and conditions of the Creative Commons Attribution license (http://creativecommons.org/licenses/by/4.0/). 